\title{
Serum and Adipose Tissue Lipids in Children Receiving Medium-chain Triglyceride Diets
}

\author{
I. TAMIR ${ }^{\star}$, SUSAN GOULD, AUDREY S. FOSBROOKE, AND JUNE K. LLOYD \\ From the Department of Child Health, Institute of Child Health, University of London
}

Studies of serum lipids in adults and children receiving most of their dietary fat as medium-chain triglyceride (MCT) have given variable results. Uzawa et al. (1964) showed that significant and maintained hypertriglyceridaemia occurred in individuals in calorie balance, whereas in hypocaloric states no such change was found. A slight fall in serum cholesterol levels was observed in 8 adults when MCT was exchanged isocalorically for long-chain triglyceride (LCT) (Hashim, Arteaga, and Van Itallie, 1960; Roels and Hashim, 1962). On the other hand, Cancio and Menéndez-Corrada (1964) in their study of adults with tropical sprue showed a rise in the initially low levels of total lipids and cholesterol when an MCT diet was given. In children with cystic fibrosis given MCT, Kuo and Huang (1965) observed an increase in plasma triglyceride in young infants but not in older children; plasma cholesterol and phospholipid levels were unaffected.

In this paper, we report the effect of an MCT diet on the concentration of serum triglyceride, cholesterol, and phospholipids, and on the fatty acid composition of serum triglyceride and phospholipids and adipose tissue triglyceride in children with various malabsorptive disorders.

\section{Patients and Methods}

Patients. The patients studied are listed in Table I. The clinical details are reported in the previous paper (Leyland et al., 1969). In 5 children the immediate effects of MCT on the serum lipids were studied by analysing blood samples before and 2, 5, 12, and 21 days after an isocaloric exchange of MCT for LCT. A diet of known composition ('pre-MCT diet') was given for one week before MCT was introduced; the substitution of MCT for LCT was made gradually over 3 days in order to avoid gastro-intestinal side-effects. The composition of the 'pre-MCT' and MCT diets

Received August 30, 1968.

* Present address: Municipal Hospitals, Tel-Aviv, Israel. is given in Table II; the total calorie intake and the proportion of carbohydrate and protein were kept constant throughout the study period.

In 9 children the long-term effects of the MCT diet on serum lipid concentrations and fatty acid composition were studied by analysing blood taken at intervals for various periods up to 28 months.

In 5 children the fatty acid composition of adipose tissue triglyceride was studied 5-24 months after the start of the MCT diet, and in 3 children analyses were made within 3 weeks of starting the diet.

Methods. Venous blood was obtained in the fasting state and lipids were extracted from the serum into ethanol/diethyl ether. Triglyceride concentration together with fatty acid composition was estimated by the method of Fosbrooke and Tamir (1968), total cholesterol using a ferric chloride method on the autoanalyser (Technicon N24A), and total phospholipids (lipid $P \times 25)$ by a modification of the method of Bartlett (1959). The four major phospholipid fractions (phosphatidyl choline, phosphatidyl ethanolamine, sphingomyelin, and lysophosphatidyl choline) were estimated individually after separation by thin-layer chromatography on silica gel $\mathrm{H}$ (solvent system: chloroform/methanol/acetic acid/water: 97/38/4/9). The fatty acid composition of phosphatidyl choline and sphingomyelin was determined by gas-liquid chromatography (at $175{ }^{\circ} \mathrm{C}$.) of the methyl esters prepared after overnight methylation as described for triglyceride (Fosbrooke and Tamir, 1968).

Adipose tissue was obtained from the subcutaneous fat of the buttock by aspiration through a Vim Silverman needle into a dry syringe, homogenized in a Griffith's tube, and the lipids extracted into chloroform/methanol (2/1). The fatty acid composition of the triglyceride was determined as described for serum triglyceride.

\section{Results}

Immediate effects. These are shown in Table III. No significant changes in serum cholesterol concentration occurred in 4 of the 5 children over periods of 12-21 days; in one child (Case 2) who had obstructive jaundice and a high 
TABLE I

Age, Sex, and Diagnosis of Children Treated with MCT Diets

\begin{tabular}{|c|c|c|c|c|c|}
\hline Case No. & Sex & $\begin{array}{c}\text { Age at } \\
\text { yr. }\end{array}$ & $\begin{array}{l}\text { of Diet } \\
\text { mth. }\end{array}$ & Diagnosis & $\begin{array}{c}\text { Duration of Dietary Study } \\
\text { (mth.) }\end{array}$ \\
\hline $\begin{array}{r}1 \\
2 \\
3 \\
4 \\
5 \\
6 \\
9 \\
10 \\
11 \\
12 \\
13\end{array}$ & $\begin{array}{l}\mathbf{F} \\
\mathbf{M} \\
\mathbf{M} \\
\mathbf{F} \\
\mathbf{M} \\
\mathbf{M} \\
\mathbf{M} \\
\mathbf{F} \\
\mathbf{F} \\
\mathbf{F} \\
\mathbf{M}\end{array}$ & $\begin{array}{r}2 \\
15 \\
8 \\
8 \\
10 \\
3 \\
6 \\
6 \\
8 \\
10\end{array}$ & $\begin{array}{l}9 \\
0 \\
7 \\
2 \\
1 \\
3 \\
7 \\
3 \\
5 \\
2 \\
1\end{array}$ & $\begin{array}{l}\text { Obstructive jaundice } \\
\text { Obstructive jaundice } \\
\text { Obstructive jaundice } \\
\text { Pancreatic insufficiency and enterocolitis } \\
\text { Pancreatic insufficiency and neutropenia } \\
\text { Pancreatic insufficiency and neutropenia } \\
\text { Intestinal lymphangiectasia } \\
\text { Intestinal lymphangiectasia } \\
\text { Intestinal lymphangiectasia } \\
\text { Intestinal lymphangiectasia } \\
\text { Intestinal lymphangiectasia }\end{array}$ & $\begin{array}{r}10 \\
8 \\
6 \\
3 \\
3 \\
28 \\
24 \\
5 \\
7 \\
1 \\
5\end{array}$ \\
\hline
\end{tabular}

TABLE II

Dietary Composition During Short-term Period of Study of Immediate Effects of MCT

\begin{tabular}{|c|c|c|c|c|c|c|c|c|c|}
\hline \multirow{3}{*}{ Case No. } & \multirow{3}{*}{$\begin{array}{c}\text { Total } \\
\text { Daily } \\
\text { Calories }\end{array}$} & \multicolumn{3}{|c|}{$\begin{array}{l}\text { Pre-MCT Diet (1 wk.) } \\
\% \text { Calories Derived From }\end{array}$} & \multirow{3}{*}{$\begin{array}{c}\text { Total } \\
\text { Daily } \\
\text { Calories }\end{array}$} & \multicolumn{4}{|c|}{$\begin{array}{l}\text { MCT Diet (up to } 3 \text { wk.) } \\
\% \text { Calories Derived From }\end{array}$} \\
\hline & & \multirow{2}{*}{$\mathrm{CHO}$} & \multirow{2}{*}{ Protein } & \multirow{2}{*}{ Fat LCT } & & \multirow{2}{*}{$\mathrm{CHO}$} & \multirow{2}{*}{ Protein } & \multicolumn{2}{|c|}{ Fat } \\
\hline & & & & & & & & LCT & $\mathrm{MCT}^{\star}$ \\
\hline $\begin{array}{r}2 \\
5 \\
10 \\
11 \\
12\end{array}$ & $\begin{array}{l}1270 \\
1800 \\
1800 \\
1620 \\
1400\end{array}$ & $\begin{array}{l}42 \\
45 \\
67 \\
45 \\
54\end{array}$ & $\begin{array}{l}17 \\
15 \\
12 \\
14 \\
15\end{array}$ & $\begin{array}{l}41 \\
40 \\
21 \\
41 \\
31\end{array}$ & $\begin{array}{l}1270 \\
1800 \\
1800 \\
1620 \\
1325\end{array}$ & $\begin{array}{l}42 \\
45 \\
67 \\
45 \\
53\end{array}$ & $\begin{array}{l}17 \\
15 \\
12 \\
14 \\
15\end{array}$ & $\begin{array}{l}3 \cdot 5 \\
4 \\
2 \cdot 5 \\
8 \\
3\end{array}$ & $\begin{array}{l}37 \cdot 5 \\
36 \\
18 \cdot 5 \\
33 \\
28\end{array}$ \\
\hline Mean values & 1578 & $50 \cdot 6$ & $14 \cdot 6$ & $34 \cdot 8$ & 1563 & $50 \cdot 6$ & $14 \cdot 6$ & $4 \cdot 2$ & 30.6 \\
\hline
\end{tabular}

^ MCT supplies $8 \cdot 3$ calories $/ \mathrm{g}$.

serum cholesterol level, a marked fall in the cholesterol concentration was observed after 12 and 21 days of MCT diet.

Serum triglyceride levels were estimated in 3 children, all of whom showed small increases $(15-55 \mathrm{mg} . / 100 \mathrm{ml}$.) after the introduction of MCT, though the concentrations remained within the normal range.

The fatty acid composition of serum triglyceride was analysed in all children. In 2 children mediumchain fatty acids were detected but only in trace quantities $(0.4 \% \quad \mathrm{C} 8: 0$ and $0.8-1 \cdot 8 \% \mathrm{C} 10: 0)$. In every case there was a reduction in the proportion of linoleic acid (C18:2) within 5 days of starting the diet; in most children the values fell still further over the next two weeks. 4 of the 5 patients showed an increase in palmitoleic acid (C16:1) after 5 days, which was maintained over the study period. One patient (Case 2) already had a high percentage of palmitoleic acid before MCT was introduced, and this remained high. No consistent changes were found in the proportions of the other major fatty acids (C14:0;16:0;18:0 and 18:1).
Long-term effects. Table IV gives the mean values for serum cholesterol and triglyceride concentrations in patients receiving MCT for periods of 3-28 months. In 6 children serial observations were made and no significant trends were observed; the data in the Table are derived from the most recent estimations for each child.

The mean total cholesterol concentration in patients before starting dietary treatment was lower than normal and no significant change occurred after the introduction of MCT. The mean triglyceride concentration was within the normal range before dietary treatment and showed a significant increase after the introduction of MCT though still remaining within the normal range. Before MCT was introduced the serum triglyceride was abnormal only in respect of a reduced proportion of linoleic acid (C18:2). On the MCT diet, the proportion of linoleic acid became further reduced and the proportions of palmitic (C16:0) and palmitoleic (C16:1) acids increased. Triglyceride analyses showed small quantities of mediumchain fatty acids $(0 \cdot 6-3 \cdot 1 \% \mathrm{C} 8: 0$ and $0 \cdot 8-2 \cdot 6 \%$ $\mathrm{C} 10: 0)$ on only a few occasions. 
Immediate Effects of MCT on Serum Cholesterol and Triglyceride

\begin{tabular}{|c|c|c|c|c|c|c|c|c|c|c|}
\hline \multirow{3}{*}{$\begin{array}{l}\text { Days } \\
\text { on } \\
\text { MCT } \\
\text { Diet }\end{array}$} & & & & & & & & & & a Lipidşgn \\
\hline & \multicolumn{5}{|c|}{ Total Cholesterol (mg./100 ml.) } & \multicolumn{4}{|c|}{ Triglyceride $(\mathrm{mg} . / 100 \mathrm{ml})}$. & \multirow{2}{*}{ 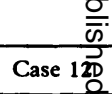 } \\
\hline & Case 2 & Case 5 & Case 10 & Case 11 & Case 12 & Case 2 & Case 5 & Case 10 & Case 11 & \\
\hline $\begin{array}{r}0 \\
2 \\
5 \\
12 \\
21\end{array}$ & $\begin{array}{l}366 \\
326 \\
340 \\
295 \\
245\end{array}$ & $\begin{array}{r}86 \\
100 \\
77 \\
90\end{array}$ & $\begin{array}{l}184 \\
195 \\
170 \\
-\end{array}$ & $\begin{array}{r}192 \\
188 \\
208 \\
182\end{array}$ & $\begin{array}{l}174 \\
171 \\
150 \\
172 \\
-\end{array}$ & $\frac{-}{-}$ & $\begin{array}{l}38 \\
87 \\
63 \\
93\end{array}$ & $\begin{array}{l}- \\
- \\
-\end{array}$ & $\begin{array}{l}54 \\
52 \\
46 \\
94 \\
55\end{array}$ & $\begin{array}{ll}27 & 0 \\
38 & \vec{\omega} \\
29 & \overrightarrow{0} \\
42 & \overrightarrow{1} \\
- & \vec{\omega}\end{array}$ \\
\hline
\end{tabular}

Table $\mathrm{V}$ gives the data for the effects of the diet on the serum phospholipids. The total phospholipid concentration was low in the 2 children studied before the start of the MCT diet, and the mean value for 7 children on dietary treatment was also significantly reduced. The distribution of the individual phospholipids was normal. In phosphatidyl choline of patients on MCT, the proportions of palmitic $(\mathrm{C16:0)}$ and oleic $(\mathrm{C} 18: 1)$ acids were increased and linoleic acid (C18:2) decreased compared with normal. In sphingomyelin the proportion of nervonic acid (C24:1) was increased, and behenic (C22:0) and lignoceric (C24:0) acids were decreased on the MCT diet. Medium-chain fatty acids were not detected in the phospholipids.

Table VI gives the fatty acid composition of adipose tissue triglyceride in 5 children on MCT diets for 5-24 months. Medium-chain fatty acids (C8:0 and $\mathrm{C10:0}$ ) were found in small quantities (less than 4.0\%). Palmitic (C16:0) and palmitoleic (C16:1) acids were present in higher concentrations, and oleic (C18:1) and linoleic (C18:2) acids in lower concentrations, than normal.

In 1 child serial studies of adipose tissue triglyceride were made weekly for the first 3 weeks after starting the diet, and in 2 other children observations were made after 2 weeks. In the single observation made before MCT was started, increased palmitoleic and decreased linoleic acids were already present. After 2 weeks the changes in long-chain fatty acids were similar to those after several months. Traces of medium-chain fatty acids were not detected until 3 weeks.

\section{Discussion}

The effect of medium-chain triglyceride diets on the serum lipids has to be considered in relation to the values present before the diet started. As

TABLE IV

Long-term Effects of MCT Diets on Serum Cholesterol and Triglyceride Concentrations and Triglyceride Fatty Acid Composition

\begin{tabular}{|c|c|c|c|c|c|c|c|c|}
\hline \multirow{2}{*}{\multicolumn{3}{|c|}{ Serum Lipids }} & \multirow{2}{*}{$\begin{array}{c}\text { Before } \\
\text { Dietary } \\
\text { Treatment } \\
\mathbf{n}=\mathbf{7} \\
(\text { mean } \pm \mathrm{SD} \text { ) }\end{array}$} & \multirow{2}{*}{$\begin{array}{c}\text { On Long-term } \\
\text { MCT Diets } \\
\text { (3-28 mth.) } \\
n=9 \\
\text { (mean } \pm \text { SD) }\end{array}$} & \multirow{2}{*}{$\begin{array}{c}\text { Normal* } \\
\text { Values } \\
\text { (mean } \pm S D)\end{array}$} & \multicolumn{3}{|c|}{ Probability for Difference Between } \\
\hline & & & & & & $\begin{array}{l}\text { Normals } \\
\text { vs. } \\
\text { Patients } \\
\text { Pre-MCT }\end{array}$ & $\begin{array}{l}\text { Patients } \\
\text { Before } \\
\text { vs. Patients } \\
\text { After MCT }\end{array}$ & $\begin{array}{l}\text { Normals } \\
\text { vs. } \\
\text { Patients } \\
\text { After MCT }\end{array}$ \\
\hline \multicolumn{3}{|c|}{$\begin{array}{l}\text { Total cholesterol }(\mathrm{mg} . / 100 \mathrm{ml} .) \\
\text { Triglyceride }(\mathrm{mg} . / 100 \mathrm{ml} .) \quad \ldots \\
\text { Major fatty acids of serum triglyceride } \\
\quad(\mathrm{g} . / 100 \mathrm{~g} . \text { fatty acid) }\end{array}$} & $\begin{aligned} 141 & \pm 37 \cdot 0 \\
47 & \pm 13 \cdot 0 t\end{aligned}$ & $\begin{array}{l}136 \pm 27 \cdot 0 \ddagger \\
66 \pm 17 \cdot 0 \S\end{array}$ & $\begin{array}{r}184 \pm 22 \cdot 0 \\
53 \pm 10 \cdot 0\end{array}$ & $\begin{array}{l}<0.02 \\
\text { NS }\end{array}$ & $\begin{array}{c}\text { NS } \\
<0.001\end{array}$ & $\begin{array}{l}<0.01 \\
<0.001\end{array}$ \\
\hline $\begin{array}{l}\text { Myristic }(\mathrm{C} 14: 0) \ldots \\
\text { Palmitic }(\mathrm{C} 16: 0) \\
\text { Palmitoleic }(\mathrm{C} 16: 1) \\
\text { Stearic }(\mathrm{C} 18: 0) \quad \ldots \\
\text { Oleic }(\mathrm{C} 18: 1) \quad \ldots \\
\text { Linoleic }(\mathrm{C} 18: 2)\end{array}$ & $\begin{array}{l}\cdots \\
\cdots \\
\cdots \\
\cdots \\
\cdots\end{array}$ & $\begin{array}{l}\cdots \\
\cdots \\
\cdots \\
\cdots \\
\cdots\end{array}$ & $\begin{array}{r}2 \cdot 3 \pm 1 \cdot 2 \\
29 \cdot 8 \pm 5 \cdot 1 \\
6 \cdot 8 \pm 3 \cdot 4 \\
3 \cdot 6 \pm 2 \cdot 3 \\
49 \cdot 6 \pm 7 \cdot 5 \\
7 \cdot 3 \pm 2 \cdot 8\end{array}$ & $\begin{array}{r}2 \cdot 9 \pm 1 \cdot 2 \\
34 \cdot 8 \pm 3 \cdot 5 \\
9 \cdot 7 \pm 2 \cdot 4 \\
4 \cdot 0 \pm 1 \cdot 4 \\
44 \cdot 0 \pm 5 \cdot 0 \\
4 \cdot 4 \pm 3 \cdot 1\end{array}$ & $\begin{array}{r}2 \cdot 7 \pm 1 \cdot 2 \\
28 \cdot 1 \pm 3 \cdot 1 \\
5 \cdot 0 \pm 0 \cdot 6 \\
4 \cdot 0 \pm 1 \cdot 2 \\
45 \cdot 7 \pm 3 \cdot 2 \\
14 \cdot 2 \pm 5 \cdot 8\end{array}$ & $\begin{array}{l}\text { NS } \\
\text { NS } \\
\text { NS } \\
\text { NS } \\
\text { NS } \\
<0 \cdot 02\end{array}$ & $\begin{array}{l}\text { NS } \\
<0 \cdot 05 \\
\text { NS } \\
\text { NS } \\
\text { NS } \\
\text { NS }\end{array}$ & $\begin{aligned} & \text { NS } \\
&<0.001 \\
&<0.001 \\
& \text { NS } \\
& \text { NS } \\
&<0.001\end{aligned}$ \\
\hline
\end{tabular}

$\star 8$ healthy subjects ( 3 children, 5 young adults).

+4 observations.

$\mp 8$ observations.

$\S 7$ observations.

NS, not significant. 
Serum and Adipose Tissue Lipids in Children Receiving Medium-chain Triglyceride Diets 183

III

Concentrations and Triglyceride Fatty Acid Composition

Individual Cases

\begin{tabular}{|c|c|c|c|c|c|c|c|c|c|}
\hline \multicolumn{5}{|c|}{ Palmitoleic Acid (C16:1) in Triglyceride (g./100 g. fatty acid) } & \multicolumn{5}{|c|}{ Linoleic Acid (C18:2) in Triglyceride (g./100 g. fatty acid) } \\
\hline Case 2 & Case 5 & Case 10 & Case 11 & Case 12 & Case 2 & Case 5 & Case 10 & Case 11 & Case 12 \\
\hline $\begin{array}{l}12 \cdot 7 \\
10.9 \\
11.0 \\
11.0 \\
11.4\end{array}$ & $\begin{array}{l}4 \cdot 0 \\
77 \cdot 1 \\
7 \cdot 4 \\
8 \cdot 2\end{array}$ & $\begin{array}{c}6 \cdot 2 \\
- \\
10 \cdot 4 \\
15 \cdot 4 \\
-\end{array}$ & $\begin{array}{l}3 \cdot 7 \\
5 \cdot 7 \\
6 \cdot 8 \\
6 \cdot 1 \\
6 \cdot 3\end{array}$ & $\begin{array}{l}4 \cdot 6 \\
6.9 \\
8 \cdot 5 \\
9 \cdot 9 \\
-\end{array}$ & $\begin{array}{l}4 \cdot 0 \\
4 \cdot 4 \\
2 \cdot 8 \\
1 \cdot 7 \\
1 \cdot 6\end{array}$ & $\begin{array}{l}9 \cdot 0 \\
-\overline{3 \cdot 1} \\
3 \cdot 7 \\
2 \cdot 2\end{array}$ & $\begin{array}{r}5 \cdot 7 \\
- \\
<1 \cdot 0 \\
4 \cdot 1 \\
-\end{array}$ & $\begin{array}{r}12 \cdot 3 \\
9 \cdot 8 \\
9 \cdot 6 \\
7 \cdot 8 \\
9 \cdot 4\end{array}$ & $\begin{array}{r}16 \cdot 0 \\
12 \cdot 6 \\
9 \cdot 2 \\
5 \cdot 3 \\
-\end{array}$ \\
\hline
\end{tabular}

TABLE V

Long-term Effects of MCT Diets on Serum Phospholipids

\begin{tabular}{|c|c|c|c|c|c|c|c|c|}
\hline \multicolumn{5}{|c|}{ Serum Phospholipids } & $\begin{array}{c}\text { Before Dietary } \\
\text { Treatment } \\
\mathbf{n}=2 \\
\text { (mean and } \\
\text { individual } \\
\text { values) }\end{array}$ & $\begin{array}{l}\text { On Long-term } \\
\text { MCT Diets } \\
\text { (3-28 mth.) } \\
n=7 \\
\text { (mean } \pm \text { SD) }\end{array}$ & $\begin{array}{c}\text { Normal } \\
\text { Values } \\
\text { mean } \pm S D\end{array}$ & $\begin{array}{c}\text { Probability } \\
\text { For Difference } \\
\text { Between Normal } \\
\text { Long-term MCT }\end{array}$ \\
\hline $\begin{array}{l}\text { Total (mg./ } 100 \mathrm{ml} .) \\
\% \text { distribution of majo } \\
\text { Lysolecithin .. } \\
\text { Sphingomyelin } \\
\text { Phosphatidyl cholin } \\
\text { Phosphatidyl ethano } \\
\text { Major fatty acids (> } \\
\text { (g./100 g. fatty acid) } \\
\text { Palmitic (C16:0) } \\
\text { Stearic (C18:0) } \\
\text { Oleic (C18:1) } \\
\text { Linoleic }(C 18: 2) \\
\text { Arachidonic (C20:4 } \\
\text { Major fatty acids (>5 } \\
\text { fatty acid) } \\
\text { Palmitic (C16:0) } \\
\text { Stearic (C18:0) } \\
\text { Behenic (C22:0) } \\
\text { Lignoceric (C24:0) } \\
\text { Nervonic (C24:1) }\end{array}$ & 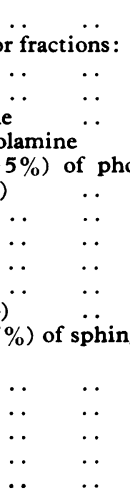 & $\begin{array}{c}\ldots \\
\ldots \\
\ldots \\
\ldots \\
\ldots \\
\text { pha } \\
\ldots \\
\ldots \\
\ldots \\
\ldots \\
\ldots\end{array}$ & $\begin{array}{c}\cdots \\
\cdots \\
\cdots \\
\cdots \\
\text { yl c } \\
\cdots \\
\cdots \\
\cdots \\
\cdots \\
\cdots\end{array}$ & \begin{tabular}{c|}
$\ldots$ \\
$\ldots$ \\
$\ldots$ \\
$\ldots$ \\
$\ldots$ \\
ine \\
$\ldots$ \\
$\ldots$ \\
$\ldots$ \\
$\ldots$ \\
$\ldots$ \\
g. \\
$\ldots$ \\
$\ldots$ \\
$\ldots$ \\
$\ldots$
\end{tabular} & $\begin{array}{r}36 \cdot 6(37 \cdot 7,35 \cdot 5) \\
14 \cdot 7(14 \cdot 3,15 \cdot 0) \\
15 \cdot 1(13 \cdot 1,17 \cdot 1) \\
17 \cdot 4(15 \cdot 1,19 \cdot 8) \\
8 \cdot 4(9 \cdot 8,7 \cdot 1) \\
\\
45 \cdot 9(45 \cdot 5,46 \cdot 3) \\
10 \cdot 7(8 \cdot 6,12 \cdot 8) \\
9 \cdot 8(12 \cdot 6,7 \cdot 0) \\
6 \cdot 1(7 \cdot 6,4 \cdot 6) \\
14 \cdot 0(12 \cdot 0,15 \cdot 9)\end{array}$ & $\begin{array}{r}146 \pm 14 \cdot 3 \\
11 \cdot 4 \pm 2 \cdot 9 \\
17 \cdot 4 \pm 2 \cdot 7 \\
66 \cdot 6 \pm 2 \cdot 4 \\
4 \cdot 6 \pm 1 \cdot 8\end{array}$ & $\begin{array}{r}34 \cdot 5 \pm 3 \cdot 3 \\
14 \cdot 6 \pm 1 \cdot 3 \\
12 \cdot 8 \pm 2 \cdot 7 \\
22 \cdot 5 \pm 3 \cdot 4 \\
7 \cdot 8 \pm 1 \cdot 5 \\
\\
36 \cdot 8 \pm 5 \cdot 4 \\
9 \cdot 8 \pm 1 \cdot 6 \\
15 \cdot 6 \pm 2 \cdot 5 \\
8 \cdot 4 \pm 2 \cdot 3 \\
14 \cdot 2 \pm 2 \cdot 6\end{array}$ & $\begin{array}{l}<0.001 \\
\text { NS } \\
<0.01 \\
<0.001 \\
\text { NS } \\
\\
\text { NS } \\
\text { NS } \\
<0.001 \\
<0.05 \\
<0.001\end{array}$ \\
\hline
\end{tabular}

$\star 10$ healthy subjects ( 3 children and 7 young adults).

TABLE VI

Fatty Acid Composition of Adipose Tissue Triglyceride in Children Receiving MCT Diets for 5-24 months

\begin{tabular}{|c|c|c|c|}
\hline $\begin{array}{c}\text { Adipose Tissue } \\
\text { Triglyceride } \\
\text { Major Fatty Acids } \\
\text { (g./100 g. total fatty acid) }\end{array}$ & $\begin{array}{c}\text { Children on } \\
\text { MCT Diets } \\
(n=5) \\
(\text { mean } \pm \text { SD })\end{array}$ & $\begin{array}{c}\text { Normal } \\
\text { Values } \\
(\text { mean } \pm S D)\end{array}$ & Probability \\
\hline $\begin{array}{ll}\text { Myristic }(\mathrm{C} 14: 0) & \ldots \\
\text { Palmitic }(\mathrm{C} 16: 0) & \ldots \\
\text { Palmitoleic }(\mathrm{C} 16: 1) & \ldots \\
\text { Stearic }(\mathrm{C} 18: 0) & \ldots \\
\text { Oleic }(\mathrm{C} 18: 1) \ldots & \ldots \\
\text { Linoleic }(\mathrm{C} 18: 2) & \ldots\end{array}$ & $\begin{array}{r}5 \cdot 6 \pm 1 \cdot 1 \\
29 \cdot 6 \pm 2 \cdot 7 \\
14 \cdot 8 \pm 3 \cdot 9 \\
3 \cdot 6 \pm 1 \cdot 5 \\
39 \cdot 0 \pm 8 \cdot 1 \\
4 \cdot 5 \pm 3 \cdot 6\end{array}$ & $\begin{array}{r}4 \cdot 7 \pm 0 \cdot 6 \\
24 \cdot 8 \pm 2 \cdot 7 \\
6 \cdot 5 \pm 2 \cdot 4 \\
5 \cdot 5 \pm 1 \cdot 6 \\
47 \cdot 6 \pm 2 \cdot 7 \\
9 \cdot 5 \pm 2 \cdot 5\end{array}$ & $\begin{array}{l}\text { NS } \\
0.01 \\
0.002 \\
\text { NS } \\
0.05 \\
0.05\end{array}$ \\
\hline
\end{tabular}

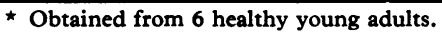


malabsorption of fat was present in the majority of the children (Leyland et al., 1969), it was to be expected that the mean levels of serum cholesterol and phospholipid would be lower than normal. The reduction in steatorrhoea resulting from the use of MCT diets is due to the low intake of ordinary fat (long-chain triglyceride), and the fact that the concentrations of serum cholesterol and phospholipids did not rise significantly in the majority of patients on dietary treatment is probably related to the low LCT intake. Our findings agree with those of Kuo and Huang (1965) in children with cystic fibrosis treated with MCT, but differ from those of Cancio and MenéndezCorrada (1964) who found that the initial low levels of serum cholesterol increased towards normal in adults with tropical sprue when given MCT. Hypocholesterolaemia has been reported by Hashim et al. (1960) and Roels and Hashim (1962) when MCT is exchanged isocalorically for butter. Pinter, Goldsmith, and Van Itallie (1966) have shown that the absorption of cholesterol is impaired during MCT feeding, and postulate that there may be partial interruption of the enterohepatic circulation of cholesterol due to depressed intestinal absorption (Pinter, 1968). In 2 of our patients (Cases 1 and 2) marked changes were observed in the serum cholesterol concentration; both these children had liver disease which undoubtedly influenced the serum lipid pattern. In Case 2 initially high concentrations of serum cholesterol (and triglyceride) returned towards normal, and in Case 1 the cholesterol levels rose with deterioration in liver function.

The initial concentration of serum triglyceride did not appear to be affected by malabsorption, though the fatty acid composition showed the reduction in linoleic acid (C18:2) which is well recognized in patients having steatorrhoea (Fernandes, van de Kamer, and Weijers, 1962). The small rise in fasting levels of serum triglyceride (predominantly long-chain triglyceride), which occurred shortly after starting MCT diets, and was maintained over the period of study, suggests increased endogenous synthesis; this is confirmed by the fatty acid pattern which showed increased proportions of palmitic $(\mathrm{C} 16: 0)$ and palmitoleic acids (C16:1). Similar observations were made by Kuo and Huang (1965), though they reported increases in total triglyceride concentration only in infants under 5 months. Increased proportions of palmitoleic. acid in serum triglyceride, indicating endogenous synthesis, are also found in children on high carbohydrate diets (Segall, Tamir, and Lloyd, 1968). Indeed in our long- term studies it is impossible to divorce the effects of MCT from those of carbohydrate, as there was usually a somewhat increased proportion of carbohydrate (about $65 \%$ of total calories) in the diet. The direct effect of MCT is, however, clearly demonstrated in the short-term studies in which the amount of carbohydrate was limited to $50 \%$. Increases in palmitoleic acid were found in some patients after only 2 days, and were more marked by 5 days. Increases in palmitoleic acid have also been shown during the course (60-90 minutes) of a single oral load of MCT (Tamir et al., 1968). The mechanism responsible for the enhanced synthesis of certain fatty acids in response to MCT feeding is not fully understood. Medium-chain fatty acids are rapidly katabolized in the liver; it is possible that octanoic acid (C8:0), because of its ready oxidation, may have a carbohydratesparing effect, and thus promote lipogenesis. Experimental evidence also suggests that 2-carbon units resulting from oxidation of MCT are added to pre-existing fatty acids which are thereby elongated (Brady, Bradley, and Trams, 1960; Sheig, 1968).

The reduction in the proportion of linoleic acid (C18:2) in serum triglyceride on MCT feeding is probably explained by the low linoleic acid content of the diet, as this acid cannot be endogenously synthesized. Kuo and Huang (1965) noted that the lowest levels of linoleic acid in their group of patients occurred in those whose diet consisted mainly of a milk formula; though the preparation used contained additional linoleic acid, the contribution from other sources was negligible.

Few studies have been made of changes in the fatty acid composition of serum phospholipids in patients receiving MCT. Kuo and Huang (1965) reported data only on phosphatidyl choline, and our findings of increases in the proportions of palmitic and oleic acids and a decrease in linoleic acid agree with theirs. We did not, however, observe the reduction in arachidonic acid (20:4) which they report. No previous studies have been reported on sphingomyelin; in this fraction we found a marked increase in the proportion of nervonic acid (C24:1) and decreases in behenic (C22:0) and lignoceric (24:0) acids. Some of these abnormalities, especially the decrease in linoleic acid in phosphatidyl choline, may result from the underlying malabsorption. Unfortunately we were only able to make detailed studies of the phospholipids before MCT was started in 2 patients. Our limited data suggest that MCT caused a further reduction in linoleic acid in phosphatidyl 
choline, and an increase in nervonic acid in sphingomyelin. Nervonic acid (24:1) can be synthesized from oleic acid (C18:1) by the addition of three 2-carbon units (Fulco and Mead, 1961); it is possible that an increased supply of 2-carbon units produced by the oxidation of MCT enhances the production of nervonic acid. As decreases in behenic (C22:0) and lignoceric (C24:0) acids were observed in one patient before MCT, the effect of MCT on the proportions of these fatty acids cannot be defined.

Analyses of adipose tissue triglyceride in our patients agree with those reported by Kuo and Huang (1965) in children with cystic fibrosis treated with MCT. In both series the proportion of palmitic acid was increased and that of oleic and linoleic acids decreased; in addition, in our patients palmitoleic acid was increased. These findings again indicate endogenous lipogenesis, and Kuo and Huang have shown that the changes are most marked in those children receiving the largest proportion of MCT in their diets. As with the serum triglyceride, we cannot say whether the long-chain fatty acid changes we observed were a consequence of feeding MCT, or of the associated increase in the proportion of carbohydrate calories. Our one pre-MCT observation was in a patient on a reduced-fat, increased-carbohydrate diet, and this showed the same long-chain fatty acid composition as we report in patients receiving MCT. The findings of only small amounts of medium-chain fatty acids (C8:0 and $\mathrm{C10:0}$ ), even after periods of 2 years, is in keeping with their rapid rate of metabolism.

No clinical evidence of linoleic acid deficiency has so far been found in children on MCT diets; Kuo and Huang (1965) followed up their patients for 9 months and we have observed children for up to 3 years. We have not usually given supplements of linoleic acid; an attempt to do so in one patient resulted in diarrhoea, presumably due to poor absorption of this long-chain fatty acid. Kuo and Huang found that the incorporation of $3 \%$ linoleic acid in an MCT formula did not significantly raise the linoleic acid content of serum and adipose tissue. We doubt whether linoleic acid supplements are necessary for older children, but lack experience with infants for whom additional linoleic acid may be required, especially in the first few months of life. Children receiving MCT diets still require long-term follow-up.

\section{Summary}

The isocaloric exchange of medium-chain triglyceride for dietary long-chain triglyceride over a three-week period in 5 children with malabsorption resulted in a slight increase in serum triglyceride concentration. There was a prompt and sustained reduction in the proportion of linoleic acid, and an increase in the proportion of palmitoleic acid in serum triglyceride in which medium-chain fatty acids appeared in trace quantities only.

The use of medium-chain triglyceride diets for 3-28 months in 10 children had no significant effect on the concentrations of serum cholesterol or phospholipid; the triglyceride concentration was higher than the pre-treatment value but did not exceed the normal range. In serum triglyceride and phosphatidyl choline the proportion of palmitic acid was increased and that of linoleic acid decreased. In addition, palmitoleic acid was increased in triglyceride, oleic acid in phosphatidyl choline, and nervonic acid in sphingomyelin. Only trace quantitites of medium-chain fatty acids were detected in serum triglyceride and none in the phospholipids.

Analysis of adipose tissue triglyceride in 5 children after 5-24 months of dietary treatment showed small quantities of medium-chain fatty acids (less than $4 \%$ ), increased proportions of palmitic and palmitoleic acids, and decreased proportions of oleic and linoleic acids.

No clinical evidence of linoleic acid deficiency was found.

We are grateful to our colleagues for allowing us to study their patients, to Miss D. M. Francis and Mrs. C. Carter for dietetic help, to the Mead Johnson Company for supplies of MCT, and to the Medical Research Council for financial assistance.

\section{REFERENCES}

Bartlett, G. R. (1959). Phosphorus assay in column chromatography. f. biol. Chem., 234, 466.

Brady, R. O., Bradley, R. M., and Trams, E. G. (1960), Biosynthesis of fatty acids. I. Studies with enzymes obtained from liver. ibid., 235, 3093.

Cancio, M., and Menéndez-Corrada, R. (1964). Absorption of medium chain triglycerides in tropical sprue. Proc. Soc. exp. Biol. (N.Y.), 117, 182.

Fernandes, J., van de Kamer, J. H., and Weijers, H. A. (1962). Differences in absorption of the various fatty acids studied in children with steatorrhea. $\mathcal{f}$. clin. Invest., 41, 488.

Fosbrooke, A. S., and Tamir, I. (1968). A modified method for the preparation of methyl esters of a mixture of medium-chain and long-chain fatty acids. Clin. chim. Acta, 20, 517.

Fulco, A. J., and Mead, J. F. (1961). The biosynthesis of lignoceric, cerebronic, and nervonic acids. $\mathcal{F}$. biol. Chem., 236, 2416

Hashim, S. A., Arteaga, A., and Van Itallie, T. B. (1960). Effect of a saturated medium-chain triglyceride on serum-lipids in man. Lancet, 1, 1105.

Kuo, P. T., and Huang, N. N. (1965). The effect of medium chain triglyceride upon fat absorption and plasma lipids and depot fat of children with cystic fibrosis of the pancreas. f. clin. Invest, 44, 1924.

Leyland, F. C., Fosbrooke, A. S., Lloyd, J. K., Segall, M. M., Tamir, I., Tomkins, R., ana Wolff, O. H. (1969). Use of 
medium-chain triglyceride diets in children with malabsorption. Arch. Dis. Childh., 44, 170.

Pinter, K. G. (1968). Discussion of the metabolic fate of medium chain triglycerides. In Medium Chain Triglycerides, p. 63. Ed. by J. R. Senior. University of Pennsylvania Press, Philadelphia.

_, Goldsmith, G. A., and Van Itallie, T. B. (1966). Effect of various fats on cholesterol ester metabolism in man. Amer. f. clin. Nutr., 18, 305.

Roels, O. A., and Hashim, S. A. (1962). Influence of fatty acids on serum cholesterol. Fed. Proc., 21, (Suppl. 2), 71.

Segall, M. M., Tamir, I., and Lloyd, J. K. (1968). Carbohydrateinduction of hypertriglyceridaemia in children. Diabetologia, $4,175$.

Sheig, R. (1968). Hepatic metabolism of medium chain fatty acids. In Medium Chain Triglycerides, p. 39 . Ed by J. R. Senior. University of Pennsylvania Press, Philadelphia.
Tamir, I., Grant, D. B., Fosbrooke, A. S., Segall, M. M., and Lloyd, J. K. (1968). Effects of a single oral load of mediumchain triglyceride on serum lipid and insulin levels in man. 7. Lipid Res., 9, 661.

Technicon method sheet number N 24A, Technicon Instruments Ltd., Chertsey, Surrey.

Uzawa, H., Schlierf, G., Chirman, S., Michaels, G., Wood, P., and Kinsell, L. W. (1964). Hypertriglyceridemia resulting from the intake of medium chain triglycerides. Amer. F. clin. Nutr., 15, 365.

Correspondence to Dr. June K. Lloyd, Institute of Child Health, Guilford Street, London W.C.1. 